\title{
PYRAZINAMIDE/PYRAZINOIC ACID RESISTANCE IN MYCOBACTERIUM TUBERCULOSIS: RECENT FINDINGS AND IMPLICATIONS FOR IMPROVING THE TREATMENT OF TUBERCULOSIS
}

\author{
R.M. Anthony' ${ }^{1}$ A.L. den Hertog ${ }^{2}$ \\ ${ }^{1}$ National Institute for Public Health and the Environment, Bilthoven, The Netherlands \\ ${ }^{2}$ Institute for Life Sciences and Chemistry, HU University of Applied Sciences, Utrecht, The Netherlands
}

\begin{abstract}
Pyrazinamide (PZA) is unique in that it is a component of the first line therapy for drug sensitive tuberculosis and in most current and experimental treatments also for multi drug resistant tuberculosis. Furthermore, PZA has been shown to help to ensure lasting cure and prevent relapse in shorter multi drug regimens. PZA is a prodrug. Mycobacterial tuberculosis (MTB) PncA enzyme activates the anti-mycobacterial prodrug PZA by transforming it into pyrazinoic acid (POA). The majority of clinical PZA resistant isolates contain mutations within the $p n c A$ gene and therefore remain sensitive to POA as they no longer activate PZA. Resistance to the active compound POA requires an alternative resistance mechanism and in vitro selected spontaneous MTB POA resistant mutants typically acquire a range of mutations in panD or mutations in one of a series of genes most of which are associated with the regulation of the bacterial stringent response. Clinically isolated PZA resistant MTB strains resistant to PZA and POA with mutations in any of these genes are unusual. Thus, it is likely the stringent response is critical for MTB in vivo and a damaged stringent response results in at least a reduction in fitness. Various lead compounds that disrupt the MTB stringent response have been identified that might form the basis for drugs with activity against latent mycobacteria with the potential to shorten tuberculosis treatment. Here we discuss the role of latency in the lifecycle of MTB and possible links to the activity PZA with a focus on potential new targets and drugs.
\end{abstract}

Key words: Mycobacterium tuberculosis, drug resistance, pyrazinamide, pyrazinoic acid, latent tuberculosis.

\section{УСТОЙЧИВОСТЬ MYСОВАСТЕRIUM TUBERCULOSIS К ПИРАЗИНАМИДУ/ПИРАЗИНОЕВОЙ КИСЛОТЕ: НОВЫЕ СВЕДЕНИЯ И ИХ ЗНАЧЕНИЕ ДЛЯ ПОВЫШЕНИЯ ЭФФЕКТИВНОСТИ ЛЕЧЕНИЯ ТУБЕРКУЛЕЗА}

Энтони Р.М. ${ }^{1}$, Ден Хертог А.Л. ${ }^{2}$

${ }^{1}$ Национальный институт общественного здоровья и окружающей среды, г. Билтховен, Нидерланды

${ }^{2}$ Институт медико-биологических наук ихимии, Университет прикладных наук, г. Утрехт, Нидерланды

Резюме. Пиразинамид (PZA) уникален тем, что является противотуберкулезным препаратом первого ряда как при лечении лекарственно-чувствительного туберкулеза, так и компонентом современных курсов лечения мультирезистентного туберкулеза. Также было показано, что PZA помогает обеспечить длительное лече-

\author{
Адрес для переписки: \\ Ричард М. Энтони \\ а/я 1, 3720 БА Билтховен, Нидерланды, Национальный институт \\ общественного здоровья и окружающей среды \\ Тел.: +31302742363. Факс: +31302744418 \\ E-mail: richard.anthony@rivm.nl
}

\section{Библиографическое описание:}

Энтони Р.М., Ден Хертог А.Л. Устойчивость Mycobacterium tuberculosis к пиразинамиду/пиразиноевой кислоте: новые сведения и их значение для повышения эффективности лечения туберкулеза // Инфекция и иммунитет. 2018. Т. 8, № 4. С. 425-434. doi: 10.15789/2220-7619-2018$4-425-434$

(c) Anthony R.M., den Hertog A.L., 2018
Contacts:

Richard M. Anthony

P.O. Box 1, 3720 BA Bilthoven, The Netherlands,

National Institute for Public Health and the Environment (RIVM). Phone: +31302742363. Fax: +31302744418.

E-mail: richard.anthony@rivm.nl

\section{Citation:}

Anthony R.M., den Hertog A.L. Pyrazinamide/pyrazinoic acid resistance in Mycobacterium tuberculosis; recent findings and implications for improving the treatment of tuberculosis // Russian Journal of Infection and Immunity = Infektsiya i immunitet, 2018, vol. 8, no. 4, pp. 425-434. doi: 10.15789/2220-7619-2018-4-425-434

DOI: http://dx.doi.org/10.15789/2220-7619-2018-4-425-434 
ние и предотвратить рецидив в более коротких схемах приема нескольких лекарств. Пиразинамид является неактивным пролекарством и фермент PncA Mycobacterium tuberculosis превращает его в активную форму пиразиноевую кислоту (РОА). Большинство клинических PZA-резистентных штаммов содержат мутации внутри гена $p n c A$ и поэтому остаются восприимчивыми к POA, поскольку не активируют РZА. Устойчивость к активному соединению РОА требует альтернативного механизма резистентности, и полученные in vitro POA-резистентные спонтанные мутанты МТВ имеют ряд мутаций в гене panD или в серии генов, большинство из которых связаны с регуляцией строгого ответа бактерий. Клинические штаммы МТВ, устойчивые к PZA и РОА с мутациями в любом из этих генов, являются нетипичными. Таким образом, вероятно, строгий ответ имеет важное значение для МТВ в условиях in vivo, а нарушенный ответ приводит к снижению жизнеспособности микроорганизма. Были идентифицированы различные лекарственные соединения-прототипы, нарушающие строгий ответ МТВ, которые могут стать основой для препаратов с активностью против латентных форм микобактерий с целью сокращения сроков противотуберкулезного лечения. В данном обзоре мы обсуждаем роль латентного периода в жизненном цикле МТВ и возможные связи с активностью PZA с особым вниманием к потенциально новым мишенями и препаратам.

Ключевые слова: Mycobacterium tuberculosis, лекарственная устойчивость, пиразинамид, пиразиноевая кислота, латентный туберкулез.

\section{Latency and the activity of (PZA) POA}

The critical importance of bacterial latency on the epidemiology and treatment of tuberculosis is widely accepted [11]. Lethal infectious diseases as well as transient infections that result in protective immunity require a continuous supply of naive hosts to be maintained in a population. Mycobacterium tuberculosis (MTB) adopts a distinct strategy establishing active infections in only a small proportion of individuals and latent infection in the majority of the infected population. Latent TB infections may spontaneously clear, reactivate or die with the host. The continuing longterm success of $M$. tuberculosis is thus largely due to its ability to (undetected) spread in a population by establishing large numbers of slowly progressing incipient or dormant infections [14]. Subclinical MTB infections have the potential to transform into new transmittable active infections, predominantly in vulnerable populations, maintaining the epidemic in a human population over a long period $[25,37]$. To establish a long-term latent infection requires the infecting mycobacteria to respond effectively to stress and to have the capacity to enter a dormant/latent phenotype (variously termed; latent, fat lazy, viable non-culturable, persister). The transition to these phenotypes thus appears to be critical for the long term success of MTB and we will argue here is closely linked to transmission dynamics, treatment outcomes, and probably also the emergence of drug resistant clones.

PZA is a pro drug which can be modified by the mycobacterial enzyme PncA to form the active compound POA. Recent reports demonstrate that resistance to pyrazinoic acid, a drug primarily active against stressed/dormant MTB in vitro can be caused by disrupting the stress responses resulting in the a failure to express the sensitive phenotype. As regulation of bacterial stress responses in this pathogen resulting in a dormant/latent phenotype is essential for the spread and survival of the MTB species, this form of resistance comes with a cost. And it is thus logical to investigate the disrupted stress responses seen in PZA and POA resistant strains, and use these data to identify potential targets for new drugs.

A further complication is neither PZA nor POA show any activity in routine culture, an effect is only seen when cultured bacteria are subjected to environmental stress. Typically an acidic growth medium is used for sensitivity testing, but a wide range of other stresses, that result in a switch to a latent/ dormant phenotype, have a similar effect $[30,46]$. In order to identify the target of POA multiple groups have generated POA resistant mutants in vitro and identified mutations in a range of genes, for example: $p a n D, c l p C 1$, and $g p s I[26,45,55,66,67]$. Recent evidence suggests panD is the primary target of POA $[5,26]$ therefore, other inhibitors of the pantothenate synthetase pathway [13] would be expected to have similar activity to PZA/POA against MTB under stressed conditions.

Apart from mutations in the likely primary target of POA panD, many of the mutations observed in spontaneous in vitro POA resistant mutants are the result of a damaged ability to enter the stressed state in which the activity of POA is inhibitory for bacterial growth $[5,26]$.

\section{Disrupting the stringent response}

Based on the range of genes identified in in vitro POA resistant spontaneous mutants the stringent response appears to play a key role in susceptibility to POA. The bacterial stringent response is a specific and very rapid cascade response to a change in environment. In $E$. coli the stringent response has been shown to be induced within seconds and is initiated by the accumulation of the so called stringent response alarmone (p)ppGpp [6]. This 
response was detected 20 minutes after $M$. tuberculosis log-phase cultures were transferred into nutrient free buffer and (p)ppGpp declined to a new steady state by 90 to $120 \mathrm{~min}$ [57]. Interestingly, an enzyme (Gps1) involved in the metabolism of (p)ppGpp was recently suggested as a new target for POA after it was observed in 4 clinical PZA resistant isolates with wildtype $p n c A, p a n D$ and $c l p C 1$ [45]. When this gene (gps1) was mutated in a sensitive strain the PZA MIC was increased. An altered enzymatic activity of mutated Gps1 in the presence and absence of POA was also demonstrated. Based on the activity of the mutant gene in the presence of POA the authors suggested Gps1 as yet another target of POA [45]. This may be correct but the role of gps 1 in the initiation of the stringent response suggests that absence of the wild type gps 1 may disrupt the regulation of entry into a fully POA susceptible phenotype [5].

Because of its importance for the regulation of latency and virulence in multiple species, the bacterial stringent response has already received attention as a potential drug target. A compound (relacin) structurally similar to the alarmone (p)ppGpp has been shown to disrupt the bacterial stringent response
[64]. Relacin and related compounds are of interest also against MTB [7] but to our knowledge have not been investigated in detail.

In most bacteria the $\mathrm{Clp}$ protease complex is a non-essential ATP-dependent protease that regulates the response to various stresses. The Clp protease complex is composed of two heptameric sections $\mathrm{ClpP} 1$ and $\mathrm{ClpP} 2$ which are involved in substrate unfolding and breakdown into short peptides. In M. tuberculosis the ClpP1 ClpP2 complex is active when bound to either hexameric $\mathrm{ClpX}$ or $\mathrm{ClpC1}$. In M. tuberculosis $\mathrm{ClpX}$ and $\mathrm{ClpC} 1$ are both essential and involved in substrate recognition and specificity $[36,49]$. Along with panD point mutations in $\operatorname{clpC1}$ are among the most frequently reported mutations in in vitro selected $M$. tuberculosis POA resistant mutants [26, 66, 67].

It has been proposed that $\operatorname{clpC} 1$ is involved in the stringent response by regulating CarD levels, a probable substrate of ClpP1P2 [48]. In E. coli DksA is a key regulator of the stringent response. Despite having little structural similarity mycobacterial CarD can functionally complement an $E$. coli DksA deficient mutant. Thus both DksA/CarD can work as general transcription factors when combined with

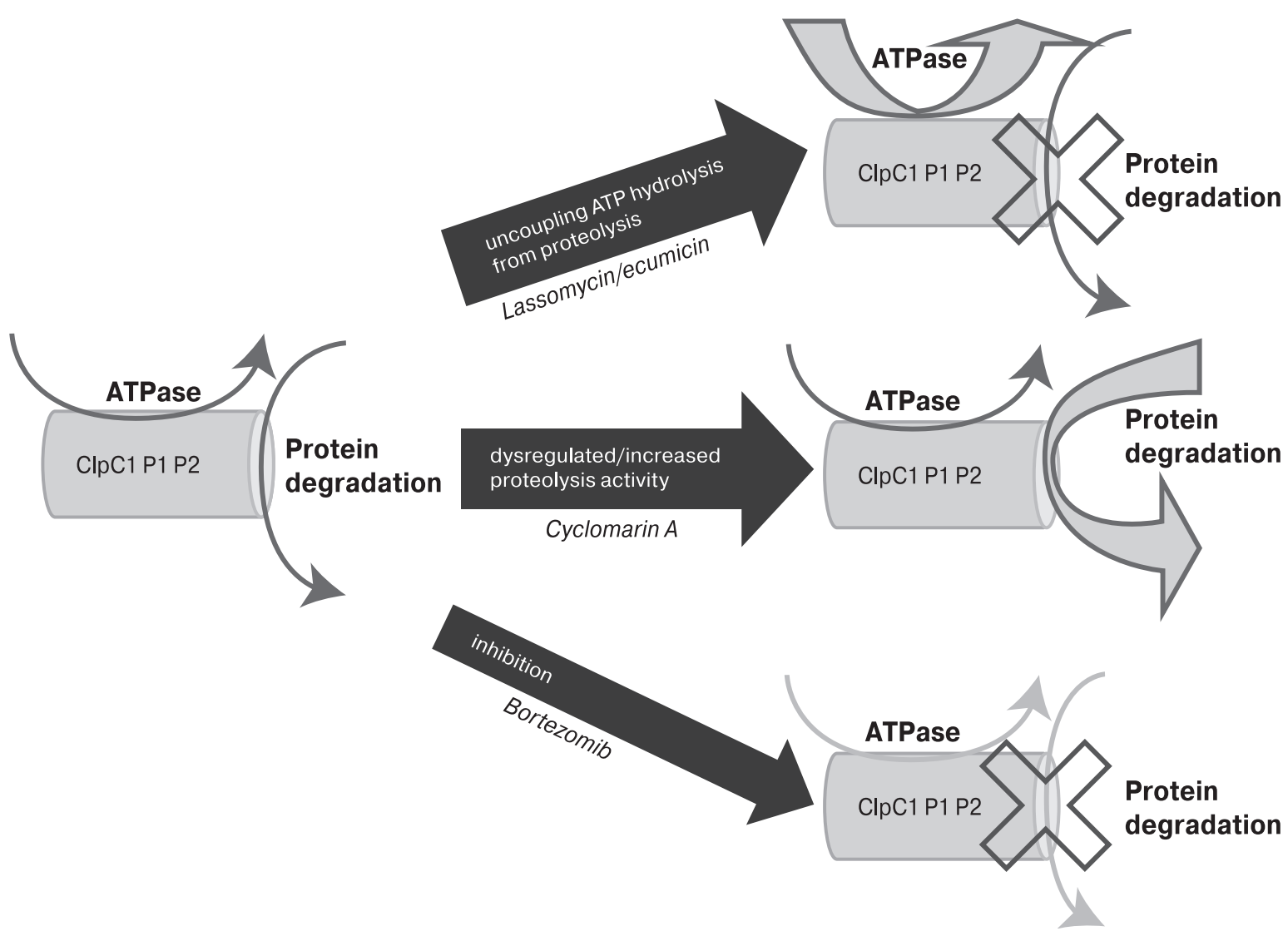

Figure. Overview of the different mechanisms of compounds known to disrupt the activity of the ClpP1P2 complex in M. tuberculosis

Proposed mechanisms are indicated in the straight arrows and compounds identified with this mechanism in italic below. ATPase and Protein degradation activity level is illustrated by the thickness of the curved arrows (left hand side normal activity), an X indicates inhibition 
the stringent response alarmone (p)ppGpp to activate the stringent response [57]. It is therefore possible that the POA resistance associated mutations seen in $c l p C 1$ are the result of a disrupted stringent response [5] due to dysregulation of the control of $c a r D$ levels in the mycobacterial cell.

The absence of the Clp protease complex in eukaryotic cells and its requirement for normal growth of $M$. tuberculosis make this complex an interesting drug target [49]. The potential of this target is further supported by the fact that although clpC1 mutants are resistant to both PZA and POA in vitro, clpC1 mutants have, to our knowledge, never been observed in PZA resistant clinical isolates. Multiple lead compounds with activity against this protease complex with different mechanisms of action have been described [36] illustrated in Fig. and briefly described here: Cyclomarin A is a naturally occurring cyclic peptide isolated from a marine Streptomyces spp. which is active against mycobacteria with reportedly good specificity [53]. Cyclomarin A appears to act by binding to $\mathrm{ClpC1}$ and dysregulating the proteolysis activity pf the MTB ClpC1P1P2 complex resulting in uncontrolled protein degradation [60]. Two other cyclic and looped peptides, lassomycin and ecumicin found after screening libraries of extracts obtained from actinomycetes, have also been reported to disrupt the activity of ClpC1P1P2 activity but by a different mechanism, uncoupling the ATPase activity from the proteolysis activity [20, 22]. These are far from being fully developed drugs but lassomycin demonstrated good specificity with activity against mycobacterial $\mathrm{ClpC} 1$ but none of the other bacterial ClpC homologs or eukaryotic proteases screened [22]. Finally, bortezomib is a compound which disrupts the MTB ClpC1P1P2 proteolytic catalytic sites [42]. Unfortunately, as this compound is used as a proteasome inhibitor approved by the U.S. FDA for the treatment of human multiple myeloma [1] it lacks (myco)bacterial specificity. However, recent work on derivatives of bortezomib, by the group who identified the potential of this compound, demonstrates scope for improving its specificity [43].

\section{Trans-translation and PZA?}

RpsA is a component of trans-translation, a rescue mechanism for stalled ribosomes. Although the role of rpsA mutations in PZA resistance is disputed, association studies of larger collections of clinical isolates does suggest some involvement [63]. RspA does not appear to be a target of PZA/POA, as recent work using laboratory mutants did not show any effect of PZA (POA) on trans-translation or the expression of RpsA [17], but RspA does seem to play a role in the susceptibility to PZA/POA. It has also been shown that overexpression of RpsA increases the PZA MIC
[54]. Trans-translation is also closely linked to the stringent response and the available data supports that it is probable that disturbances in the balance of these interacting pathways, may disrupt entry into a latent, pyrazinamide-susceptible phenotype [5].

Inhibitors of trans-translation have been identified and at least one (KKL-35) was shown to be active against MTB under both aerobic and anoxic conditions [3], although others have questioned KKL-35's mode of action [10].

Based on this idea above we have suggested RpsA and trans-translation do not have a direct role in the mode of action of pyrazinamide but mutations in $\operatorname{rps} A$ reduce the efficiency of a switch to a pyrazinamidesusceptible phenotype [5]. Interestingly, in 2018 a mutation in another gene $1 \mathrm{prG}$ was associated with PZA resistance in 4 POA-resistant laboratory mutants [55]. The authors speculated this mutation probably results in a state of higher metabolism during in vitro culture that antagonizes PZA/POA activity in vitro, a suggestion that appears to be analogous with our speculation on the role of $\operatorname{rps} A$ mutations [5].

\section{Novel strategies to target PZA resistant pncA mutants?}

As a clear majority of clinically PZA resistant isolates are resistant due to mutations in $p n c A$ and do not transform PZA into its active form POA [40] might it be possible to reverse this resistance? Although it has been frequently argued that the loss of the $p n c A$ gene has little or no cost this may not be the case [32]. NAD ${ }^{+}$is produced in M. tuberculosis by either the de novo or the salvage pathway. PncA is part of the NAD ${ }^{+}$salvage pathway. M. bovis PncA has dramatically reduced activity and as a result $M$. bovis is resistant to PZA and has a negative result in the niacin test [56]. The pncA gene in $M$. bovis has a single mutation (His57Asp) and does appear to retain some activity as $M$. bovis strains in which the de novo $\mathrm{NAD}^{+}$pathway is also deleted remain viable but are killed if starved of nicotinamide [62]. This indicates that either a (partially) functional de novo or active salvage pathway for $\mathrm{NAD}^{+}$is essential for the viability of the MTB complex. In support of this interpretation detailed work on these pathways suggests when the do novo pathway cannot function due to prolonged starvation recycling of $\mathrm{NAD}^{+}$by the salvage pathway prevents cell death [62]. This implies that the total loss of PncA activity, probable in a large proportion of PZA resistant $p n c A$ mutants as a result of AA substitutions frame shifts or even $p n c A$ gene deletion, will have a lethal cost under extended starvation.

Based on the argument above, either exposing the cost of a total loss of the salvage pathway or conversion of PZA to POA by another (host) pathway would be expected to restore sensitivity to PZA 
in MTB PZA resistant mutants lacking any PncA activity. Therefore, inhibition of the de novo $\mathrm{NAD}^{+}$ pathway should be lethal for PZA resistant strains with no PncA activity making this pathway a potential target for a large proportion of $\mathrm{M}(\mathrm{X}) \mathrm{DR}-\mathrm{TB}$ isolates as suggested by Vilcheze et al. in 2010 [62].

Secondly, PZA is not only converted into the active form (POA) by bacterial PncA but also in the infected patient's liver by microsomal deamidase. POA is then further metabolized by human xanthine oxidase. It has been shown that compounds inhibiting human xanthine oxidase activity, such as allopurinol, result in increased the levels of circulating pyrazinoic acid $[44,61]$ but it does not appear to be known if this increase in circulating host-derived pyrazinoic acid would restore pyrazinamide activity against infecting bacteria with $p n c A$ mutations.

\section{Preventing the accumulation of PZA resistance}

The lack of PZA activity in routine culture and an incomplete understanding of the mechanism of action have added to the complexity of optimising the use of this compound in patients. The diversity of resistance mutations in $p n c A$ in PZA resistant clinical isolates suggests ongoing selection of PZA resistance in most settings [4]. This may be a particular problem for MDR-TB patients who are not detected as infected with resistant TB at diagnosis and receive first line therapy which is in fact likely to be monotherapy with PZA supplemented with ineffective drugs [65]. PZA is usually given only for the first two months of standard TB therapy because clinical trials conducted by the British Medical Research Council in the 1960s and 1970s did not detect any benefit of PZA beyond 2 months [19]. However, an effect of PZA beyond 2 months was seen in second line regimens in a murine model [2] and treatment of MDR-TB frequently includes longer periods of PZA exposure [59]. RIF and INH are very effective at clearing replicating bacilli in an infection whereas PZA is known to be most active against difficult to eradicate non-replicating mycobacteria therefore, PZA given at the end of therapy to eradicate any remaining bacteria instead of exposing the large numbers of bacilli at the start of therapy appears logical. Furthermore delaying the use of PZA in this way should reduce the chance of inadvertent monotherapy with PZA for yet to be identified M(X)DR-TB patients starting TB therapy [4]. To our knowledge, the utility of PZA at the end of therapy vs at the beginning of therapy has not been tested.

Recent insights into the pharmacological mechanism underlying PZA's unique clinical efficacy and modelling suggest a potential benefit of PZA beyond the first 2 months in some patients [9]. This com- bined with knowledge on the mechanism of action of PZA, which has become much clearer by the efforts of different groups in the past few years, should provide a basis for trials to explore the more optimal use of this drug in multidrug regimens as well as how to time and dose new drugs with related mechanisms of action.

\section{The regulation of latency and the success of MTB strains}

Latency is critical for the success of MTB in the population and in an individual patient. It is often stated that the infectious dose of TB is low possibly as low a single viable cell [52]. This may be true but caution is warranted as routine culture often misses $>90 \%$ of viable cells [18]. Also, the observation that infections with double MIRU-VNTR bands are mixed infections that can be transmitted between patients [33] provides circumstantial evidence that new infections are often the result of larger numbers of mycobacterial cells that preserve some of the genetic diversity present in the source case. This preserved diversity within the infecting bacterial population may ultimately be useful to identify more details of transmission dynamics $[8,33,39]$. Even more interestingly, it was recently observed that patients with a higher proportion of latent bacteria in their sputum appeared more likely to transmit the disease to close contacts [16]. At first sight this may appear to be a paradox but establishing a new infection is a critical step in the life cycle of $M$. tuberculosis and expressing a phenotype able to remain viable in the environment and initiate a new infection without provoking a lethal immune response from the host could well be an essential ability for continued success. It has long been recognised that microscopically the cells in patient's sputum appear different to those in culture, being slightly more elongated and with more apparent internal structure when stained with $\mathrm{ZN}$ or auramine $\mathrm{O}$. These elongated cells with structure were studied in detail by Garton et al. (2008) [21] and termed "fat lazy bacteria". Presumably these bacteria are the subpopulation of cells that are transmitting in the study of Datta et al. (2017) [16]. Downregulation of growth in a large proportion of the mycobacteria in an infection thus appears to be normal and is probably important for efficient transmission.

The critical importance of persistence on the natural life cycle of MTB raises the possibility that different linages may have adapted their propensity to enter or exit latency as a survival strategy. The presence of bacilli simultaneously in different states in an active infection is assumed to be one of the primary reasons why the curative treatment of tuberculosis is so ineffective and requires at least 6 months to eliminate all the latent cells, even 
Table. Potential drug targets and compounds of interest likely to be active against stressed mycobacteria based on our current understanding of PZA activity

\begin{tabular}{|c|c|c|c|}
\hline Target/mechanism of action & Compounds of interest & Notes & Literature \\
\hline Alarmone (p)ppGpp analogue & Relacin & $\begin{array}{l}\text { Disrupt the stringent response shown to be active } \\
\text { against MTB }\end{array}$ & $\begin{array}{c}{[64]} \\
{[7]} \\
{[58]}\end{array}$ \\
\hline $\begin{array}{l}\text { Disruption of clpCP1P2 } \\
\text { complex activity }\end{array}$ & $\begin{array}{l}\text { Cyclomarin A } \\
\text { Bortezomib } \\
\text { Lassomycin } \\
\text { Ecumicin }\end{array}$ & $\begin{array}{l}\text { Disrupt the regulation of clpC targeted protein } \\
\text { degradation to disrupt the stress response } \\
\text { (see Fig.) }\end{array}$ & $\begin{array}{l}{[53]} \\
{[42]} \\
{[22]} \\
{[36]}\end{array}$ \\
\hline \multirow{2}{*}{$\begin{array}{l}\text { Reversion of PZA resistance } \\
\text { in pncA mutants }\end{array}$} & Alopurinol + PZA & $\begin{array}{l}\text { Inhibit host degradation of POA to increase levels } \\
\text { of host derived POA, restoring sensitivity in pncA } \\
\text { mutants }\end{array}$ & $\begin{array}{l}{[61]} \\
{[44]}\end{array}$ \\
\hline & $\begin{array}{l}\text { unidentified inhibitor } \\
\text { of the de novo NAD } \\
\text { pathway + PZA }\end{array}$ & $\begin{array}{l}\text { Inhibition of the NAD }{ }^{+} \text {de novo pathway. Loss } \\
\text { of PncA activity is predicted to make the de novo } \\
\text { pathway essential }\end{array}$ & [62] \\
\hline $\begin{array}{l}\text { Avoiding the selection } \\
\text { of de novo PZA resistance }\end{array}$ & $\begin{array}{l}\text { PZA dosed differently/ } \\
\text { given at the end } \\
\text { of therapy }\end{array}$ & $\begin{array}{l}\text { The diversity of pncA mutations suggests ongoing } \\
\text { selection of resistance in some settings }\end{array}$ & $\begin{array}{l}{[4]} \\
{[9]}\end{array}$ \\
\hline Disrution of trans-translation & KKL-35 & $\begin{array}{l}\text { Trans-translation has been shown to be essential } \\
\text { for MTB and the activity of of KKL- } 35 \text { agains MTB } \\
\text { demonstrated but the mechanism of action } \\
\text { of KKL-35 is disputed }\end{array}$ & $\begin{array}{c}{[3]} \\
{[10]}\end{array}$ \\
\hline $\begin{array}{l}\text { Alternative inhibitors } \\
\text { of pantothenate synthesis }\end{array}$ & $\begin{array}{l}\text { Unknown (sulfamoyl } \\
\text { analogues) }\end{array}$ & $\begin{array}{l}\text { Based on the ideas presented here would be } \\
\text { expected to have similar activity as PZA }\end{array}$ & [13] \\
\hline
\end{tabular}

though an active tuberculosis infection is probably effectively "cured" within the first few weeks [27]. The majority of drugs used to treat tuberculosis appear to be at best only partially effective at eliminating latent bacteria. Two notable exceptions may be pyrazinamide (PZA) and high dose rifampicin but even these compounds probably do not rapidly eliminate all persistent MTB [28, 29]. Here the discussion focusses on the bacteria but this is certainly also in part due to the location of many of these less active mycobacterial cells in tissue or granulomas where the concentration of antimicrobials is suboptimal as a result of limited penetration [23], a situation that may also help amplify resistance. Furthermore, as an active MTB infection does not usually result in protective immunity [51] the immune system of even a "virtually cured" patient may be unable to eliminate even a few reactivating MTB cells that escaped the treatment.

Differences in the propensity of strains to enter a latent phenotype may result in some strains being more likely to rapidly breakdown into active disease with others being more likely to establish latent infections. An association with specific clades with treatment failure and drug resistance is established $[24,41]$ but the explanation for this association remains controversial [12, 35]. Although representatives of virtually all genotypes of $M$. tuberculosis have independently acquired multi-drug resistance by similar mechanisms it does appear that in many settings similar genotypes are more often associated with an MDR genotype than other genotypes. This may be chance, but as these differences between lineages are consistent between different geographical areas and because first line treatment of tuberculosis is highly standardised throughout the world, it is probable that certain genotypes are more able to develop resistance or are more likely to maintain their ability to spread and cause disease after having acquired resistance. There is tantalising evidence that variation in the initial bactericidal effect of antibiotic exposure plays a role in the development of resistance in $M$. tuberculosis: it has recently been observed that when different genotypes of $M$. tuberculosis are initially exposed to rifampicin the rate of killing and initial response differs [31, 34]. The increased ability to resist exposure to an antibiotic in the absence of a specific resistance mechanism (mutation) by a proportion of the bacterial cells in a population is termed persistence. It is likely these effects are linked to differing proportions of metabolically active cells in a nutrient rich environment for different genotypes [50], termed Class 1 persistence [38], possibly a result of differences in the "magic spot" setting of the stringent response [15]. 


\section{Conclusions}

In this paper we discuss the insights that mutations seen in in vitro PZA/POA resistant strains have provided regarding the formation of a latent/dormant phenotype of TB. The increasing amount of data on POA resistance mechanisms many of which appear to disrupt the formation of these phenotypes, provides an opportunity to determine the clinical relevance of blocking this phenotype switching and research compounds capable of specifically blocking the activity of the relevant enzymes.

In the discussion above we present a series of arguments that suggests the precise regulation of latency in MTB is of critical importance for the disease process, the development of resistance, as well as the epidemiology of tuberculosis. If the argument that PZA attacks latent cells is accepted this explains the value of PZA in (shortening) tuberculosis treat- ment regimens. We further suggest that it is likely the regulation of latency is disrupted in many unsuccessful POA resistant mutants, seen in culture but rarely in clinical isolates, and compounds that disrupt related targets (Table) would be expected to also help shorten treatment duration and prevent relapse if developed into drugs.

\section{Acknowledgments}

This review formed the basis of a talk presented at the "Molecular bases of epidemiology, diagnostics, prevention and treatment of infectious diseases" congress dedicated to the $110^{\text {th }}$ anniversary of St. Petersburg Pasteur Institute December 4-6, 2018 St. Petersburg Russia and was partially funded by the Dutch Ministry of Health and a grant (5054100-98-255) from ZonMw to investigate the micro-evolution of tuberculosis during treatment.

\section{Список литературы/References}

1. Adams J., Kauffman M. Development of the proteasome inhibitor Velcade ${ }^{\mathrm{TM}}$ (Bortezomib). Cancer Invest., 2004, vol. 22, no. 2, pp. 304-311. doi: 10.1081/CNV-120030218

2. Ahmad Z., Tyagi S., Minkowski A., Peloquin C.A., Grosset J.H., Nuermberger E.L. Contribution of moxifloxacin or levofloxacin in second-line regimens with or without continuation of pyrazinamide in murine tuberculosis. Am. J. Respir. Crit. Care Med., 2013, vol. 188, no. 1, pp. 97-102. doi: 10.1164/rccm.201212-23280C

3. Alumasa J.N., Manzanillo P.S., Peterson N.D., Lundrigan T., Baughn A.D., Cox J.S., Keiler K.C. Ribosome rescue inhibitors kill actively growing and nonreplicating persister Mycobacterium tuberculosis cells. ACS Inf. Dis., 2017, vol. 3, no. 9, pp. 634-644. doi: 10.1021/acsinfecdis. $7 b 00028$

4. Anthony R.M., Cynamon M., Hoffner S., Werngren J., den Hertog A.L., van Soolingen D. Protecting pyrazinamide, a priority for improving outcomes in multidrug-resistant tuberculosis treatment. Antimicrob. Agents. Chemother., 2017, vol. 61, no. 6: e0025817. doi: $10.1128 / A A C .00258-17$

5. Anthony R.M., den Hertog A.L., van Soolingen D. 'Happy the man, who, studying nature's laws, Thro'known effects can trace the secret cause.' Do we have enough pieces to solve the pyrazinamide puzzle? J. Antimicrob. Chemother., 2018, vol. 73, no. 7, pp. 1750-1754. doi: 10.1093/jac/dky060

6. Arenz S., Abdelshahid M., Sohmen D., Payoe R., Starosta A.L., Berninghausen O., Vasili Hauryliuk V., Beckmann R., Wilson D.N. The stringent factor RelA adopts an open conformation on the ribosome to stimulate ppGpp synthesis. Nucleic Acids Res., 2016, vol. 44, no. 13, pp. 6471-6481. doi: 10.1093/nar/gkw470

7. Bag S., Das B., Dasgupta S., Bhadra R.K. Mutational analysis of the (p) ppGpp synthetase activity of the Rel enzyme of Mycobacterium tuberculosis. Arch. Microbiol., 2014, vol. 196, no. 8, pp. 575-588. doi: 10.1007/s00203-014-0996-9

8. Black P.A., De Vos M., Louw G.E., Van der Merwe R.G., Dippenaar A., Streicher E.M., Abdallah A.M., Sampson S.L., Victor T.C., Dolby T., Simpson, J.A., van Helden, P.D., Warren, R.M., Pain A. Whole genome sequencing reveals genomic heterogeneity and antibiotic purification in Mycobacterium tuberculosis isolates. BMC genomics, 2015, vol. 16, no. 1: 857. doi: 10.1186/s12864-0152067-2

9. Blanc L., Sarathy J.P., Cabrera N.A., O’Brien P., Dias-Freedman I., Mina M., Sacchettini J., Savic R.M., Gengenbacher M., Podell B.K., Prideaux B., Ioerger T., Dick T., Dartois V. Impact of immunopathology on the antituberculous activity of pyrazinamide. J. Exp. Med., 2018, vol. 215, no. 8: 1975. doi: 10.1084/jem.20180518

10. Brunel R., Descours G., Durieux I., Doublet P., Jarraud S., Charpentier X. KKL-35 exhibits potent antibiotic activity against Legionella species independently of trans-translation inhibition. Antimicrob. Agents. Chemother., 2017, AAC-01459. doi: 10.1128/ AAC.01459-17

11. Caño-Muñiz S., Anthony R., Niemann S., Alffenaar J.W.C. New approaches and therapeutic options for Mycobacterium tuberculosis in a dormant state. Clin. Microbiol. Rev., 2018, vol. 31, no. 1: e00060-17. doi: 10.1128/CMR.00060-17

12. Carey A.F., Rock J.M., Krieger I.V., Chase M.R., Fernandez-Suarez M., Gagneux S., Sacchettini, J.C., Ioerger, T.R., Fortune S.M. TnSeq of Mycobacterium tuberculosis clinical isolates reveals strain-specific antibiotic liabilities. PLoS Pathog., 2018, vol. 14, no. 3, e1006939. doi: 10.1371/journal.ppat.1006939

13. Ciulli A., Scott D.E., Ando M., Reyes F., Saldanha S.A., Tuck K.L., Chirgadze, D.Y., Blundell, T.L., Abell C. Inhibition of Mycobacterium tuberculosis pantothenate synthetase by analogues of the reaction intermediate. ChemBioChem, 2008, vol. 9, no. 16, pp. 2606-2611. doi: 10.1002/cbic.200800437

14. Cobelens F., Kik S., Esmail H., Cirillo D.M., Lienhardt C., Matteelli A. From latent to patent: rethinking prediction of tuberculosis. The Lancet Respiratory Medicine, 2017, vol. 5, no. 4, pp. 243-244. doi: 10.1016/S2213-2600(16)30419-2 
15. Connolly L.E., Cox J.S. CarD tricks and magic spots: mechanisms of stringent control in mycobacteria. Cell Host Microbe, 2009, vol. 6, no. 1, pp. 1-2. doi: 10.1016/j.chom.2009.07.001

16. Datta S., Sherman J.M., Tovar M.A., Bravard M.A., Valencia T., Montoya R., Quino W., D’Arcy N., Ramos E.S., Gilman R.H., Evans C.A. Sputum microscopy with fluorescein diacetate predicts tuberculosis infectiousness. J. Infect. Dis., 2017, vol. 216, no. 5, pp. 514-524. doi: 10.1093/infdis/jix229

17. Dillon N.A., Peterson N.D., Feaga H.A., Keiler K.C., Baughn A.D. Anti-tubercular activity of pyrazinamide is independent of trans-translation and RpsA. Scientific Reports, 2017, vol. 7, no. 1: 6135. doi: 10.1038/s41598-017-06415-5

18. Dillon N.A., Peterson N.D., Rosen B.C., Baughn A.D. Pantothenate and pantetheine antagonize the antitubercular activity of pyrazinamide. Antimicrob. Agents Chemother., 2014, vol. 58, pp. 7258-7263. doi: 10.1128/AAC.04028-14

19. East African/British Medical Research Councils. Controlled clinical trial of four short-course (6-month) regimens of chemotherapy for treatment of pulmonary tuberculosis: second report. Lancet, 1973, vol. 1, pp. 1331-1339. doi: 10.1016/S01406736(74)91411-1

20. Gao W., Kim J.Y., Anderson J.R., Akopian T., Hong S., Jin Y.Y., Kandror O., Kim J.-W., Lee I.-A., Lee S.-W., McAlpine J.B., Mulugeta S., Sunoqrot S., Wang Y., Yang S.H., Yoon T-M., Goldberg A.L., Pauli G.F., Syh J.-W., Franzblau S.G., Cho S. The cyclic peptide ecumicin targeting ClpC1 is active against Mycobacterium tuberculosis in vivo. Antimicrob. Agents. Chemother., 2014, vol. 59, no. 2, pp. 880-889. doi: 10.1128/AAC.04054-14

21. Garton N.J., Waddell S.J., Sherratt A.L., Lee S.M., Smith R.J., Senner C., Hinds J., Rajakumar K., Adegbola R.A., Besra G.S., Butcher P.D. Cytological and transcript analyses reveal fat and lazy persister-like bacilli in tuberculous sputum. PLoS Med., 2008, vol. 5: e75. doi: 10.1371/journal.pmed.0050075

22. Gavrish E., Sit C.S., Cao S., Kandror O., Spoering A., Peoples A., Ling L., Fetterman A., Hughes D., Bissell A., Torrey H., Akopian T., Mueller A., Epstein S., Goldberg A., Clardy J., Lewis K. Lassomycin, a ribosomally synthesized cyclic peptide, kills Mycobacterium tuberculosis by targeting the ATP-dependent protease ClpC1P1P2. Chem. Biol., 2014, vol. 21, no. 4, pp. 509-518. doi: $10.1016 /$ j.chembiol.2014.01.014

23. Gillespie S.H. Evolution of drug resistance in Mycobacterium tuberculosis: clinical and molecular perspective. Antimicrob. Agents. Chemother., 2002, vol. 46, no. 2, pp. 267-274. doi: 10.1128/AAC.46.2.267-274.2002

24. Glynn J.R., Whiteley J., Bifani P.J., Kremer K., van Soolingen D. Worldwide occurrence of Beijing/W strains of Mycobacterium tuberculosis: a systematic review. Emerg. Infect. Dis., 2002, vol. 8, no. 8: 843. doi: 10.3201/eid0808.020002

25. Gomez J.E., McKinney J.D. M. tuberculosis persistence, latency, and drug tolerance. Tuberculosis, 2004 , vol. 84, no. 1, pp. $29-44$. doi: 10.1016/j.tube.2003.08.003

26. Gopal P., Tasneen R., Yee M., Lanoix J.-P., Sarathy J., Rasic G., Li L., Dartois V., Nuermberger E., Dick T. In vivo-selected pyrazinoic acid-resistant Mycobacterium tuberculosis strains harbor missense mutations in the aspartate decarboxylase PanD and the unfoldase ClpC1. ACS Infect. Dis., 2017, vol. 3, pp. 492-501. doi: 10.1021/acsinfecdis. 7 b00017

27. Honeyborne I., McHugh T.D., Phillips P.P., Bannoo S., Bateson A., Carroll N., Perrin F.M., Ronacher K., Wright L., Van Helden P.D., Walzl G. Molecular bacterial load assay, a culture-free biomarker for rapid and accurate quantification of sputum Mycobacterium tuberculosis bacillary load during treatment. J. Clin. Microbiol., 2011, vol. 49, no. 11, pp. 3905-3911. doi: 10.1128/ JCM.00547-11

28. Hu Y., Coates A.R., Mitchison D.A. Sterilising action of pyrazinamide in models of dormant and rifampicin-tolerant Mycobacterium tuberculosis. Int. J. Tuberc. Lung Dis., 2006, vol. 10, no. 3, pp. 317-322.

29. Hu Y., Mangan J.A., Dhillon J., Sole K.M., Mitchison D.A., Butcher P.D., Coates A.R. Detection of mRNA transcripts and active transcription in persistent Mycobacterium tuberculosis induced by exposure to rifampin or pyrazinamide. J. Bacteriol., 2000, vol. 182, no. 22, pp. 6358-6365. doi: 10.1128/JB.182.22.6358-6365.2000

30. Hertog A.L. den, Menting S., Pfeltz R., Warns M., Siddiqi S.H., Anthony R.M. PZA is active against Mycobacterium tuberculosis cultures at neutral pH with reduced temperature. Antimicrob. Agents. Chemother., 2016, vol. 60, no. 8, pp. 4956-4960. doi: 10.1128/ AAC.00654-16.

31. Hertog A.L. den, Menting S., van Soolingen D., Anthony R.M. Mycobacterium tuberculosis Beijing genotype resistance to transient rifampin exposure. Emerg. Infect. Dis., 2014, 20(11), 1932. doi: 10.3201/eid2011.130560

32. Hertog A.L. den, Sengstake S., Anthony R.M. Pyrazinamide resistance in Mycobacterium tuberculosis fails to bite? Pathog. Dis., 2015, vol. 73, no. 6, doi: 10.1093/femspd/ftv037

33. Jajou R., Kamst M., van Hunen R., de Zwaan C.C., Mulder A., Supply P., Anthony R., van der Hoek W., van Soolingen D. The occurrence and nature of double alleles in VNTR patterns of more than 8,000 Mycobacterium tuberculosis complex isolates in The Netherlands. J. Clin. Microbiol., 2017, vol. 56, iss. 2: e00761-17. doi: 10.1128/JCM.00761-17

34. Keijzer J. de, Mulder A., de Ru A.H., van Soolingen D., van Veelen P.A. Parallel reaction monitoring of clinical Mycobacterium tuberculosis lineages reveals pre-existent markers of rifampicin tolerance in the emerging Beijing lineage. J. Proteomics, 2017, vol. 150, pp. 9-17. doi: 10.1016/j.jprot.2016.08.022

35. Lan N.T. N., Lien H.T. K., Tung L.B., Borgdorff M.W., Kremer K., Van Soolingen D. Mycobacterium tuberculosis Beijing genotype and risk for treatment failure and relapse, Vietnam. Emerg. Infect. Dis., 2003, vol. 9, no. 12: 1633. doi: 10.3201/eid0912.030169

36. Lee H., Suh J.W. Anti-tuberculosis lead molecules from natural products targeting Mycobacterium tuberculosis ClpC1. J. Ind. Microbiol. Biotechnol., 2016, vol. 43, no. 2-3, pp. 205-212. doi: 10.1007/s10295-015-1709-3

37. Lillebaek T., Dirksen A., Baess I., Strunge B., Thomsen V.Ø., Andersen Å.B. Molecular evidence of endogenous reactivation of Mycobacterium tuberculosis after 33 years of latent infection. J. Infect. Dis., 2002, vol. 185, pp. 401-404. doi: 10.1086/338342

38. Lupoli T.J., Vaubourgeix J., Burns-Huang K., Gold B. Targeting the proteostasis network for mycobacterial drug discovery. ACS Inf. Dis., 2018, vol. 4, no. 4, pp. 478-498. doi: 10.1021/acsinfecdis. 7 b00231

39. Meehan C.J., Moris P., Kohl T.A., Pecerska J., Akter S., Merker M., Utpatel C., Beckert P., Gehre F., Lempens P., Stadler T. The relationship between transmission time and clustering methods in Mycobacterium tuberculosis epidemiology. bioRxiv, 2018, 302232. doi: $10.1101 / 302232$ 
40. Miotto P., Cabibbe A.M., Feuerriegel S., Casali N., Drobniewski F., Rodionova Y., Bakonyte D., Stakenas P., Pimkina E., Augustynowicz-Kopeć. E., Degano M. Mycobacterium tuberculosis pyrazinamide resistance determinants: a multicenter study. MBio, 2014, vol. 5, no. 5: e01819-14. doi: 10.1128/mBio.01819-14

41. Mokrousov I., Jiao W.W., Sun G.Z., Liu J.W., Valcheva V., Li M., Li M., Narvskaya O., Shen A.D. Evolution of drug resistance in different sublineages of Mycobacterium tuberculosis Beijing genotype. Antimicrob. Agents. Chemother., 2006, vol. 50, no. 8 , pp. 2820-2823. doi: 10.1128/AAC.00324-06

42. Moreira W., Ngan G.J.Y., Low J. L, Poulsen A., Chia B.C.S., Ang M.J.Y., Yap A., Fulwood J., Lakshmanan U., Lim J., Khoo A.Y.T., Flotow H., Hill J., Raju R.M., Rubin E.J., Dick T. Target mechanism-based whole-cell screening identifies bortezomib as an inhibitor of caseinolytic protease in mycobacteria. mBio, 2015, vol. 6, no. 3: e00253-15. doi: 10.1128/mBio.00253-15

43. Moreira W., Santhanakrishnan S., Dymock B.W., Dick T. Bortezomib warhead-switch confers dual activity against mycobacterial caseinolytic protease and proteasome and selectivity against human proteasome. Front. Microbiol., 2017, vol. 8: 746. doi: 10.3389/ fmicb.2017.00746

44. Naftalin C.M., Verma R., Gurumurthy M., Lu Q., Zimmerman M., Yeo B.C.M., Tan K.H., Lin W., Yu B., Dartois V., Paton N.I. Co-administration of allopurinol to increase anti-mycobacterial efficacy of pyrazinamide: evaluation in a whole-blood bactericidal activity model. Antimicrob. Agents. Chemother., 2017, vol. 61, no. 10: e00482-17. doi: 10.1128/AAC.00482-17

45. Njire M., Wang N., Wang B., Tan Y., Cai X., Liu Y., Mugweru J., Guo J., Hameed H.A., Tan S., Liu J. Pyrazinoic acid inhibits a bifunctional enzyme in Mycobacterium tuberculosis. Antimicrob. Agents Chemother., 2017, vol. 61, no. 7: e00070-17. doi: 10.1128/ AAC.00070-17

46. Peterson N.D., Rosen B.C., Dillon N.A. Baughn A.D. Uncoupling environmental pH and intrabacterial acidification from pyrazinamide susceptibility in Mycobacterium tuberculosis. Antimicrob. Agents Chemother., 2015, vol. 59, pp. 7320-7326. doi: 10.1128/ AAC.00967-15

47. Primm T.P., Andersen S.J., Mizrahi V., Avarbock D., Rubin H., Barry C.E. The stringent response of Mycobacterium tuberculosis is required for long-term survival. J. Bacteriol., 2000, vol. 182, no. 17, pp. 4889-4898. doi: 10.1128/JB.182.17.4889-4898.2000

48. Raju R.M., Jedrychowski M.P., Wei J.R., Pinkham J.T., Park A.S., O’Brien K., Rehren G., Schnappinger D., Gygi, S.P., Rubin E.J. Post-translational regulation via Clp protease is critical for survival of Mycobacterium tuberculosis. PLoS Pathog., 2014, vol. 10, no. 3: e1003994. doi: 10.1371/journal.ppat.1003994

49. Raju R.M., Unnikrishnan M., Rubin D.H., Krishnamoorthy V., Kandror O., Akopian T.N., Rubin E.J. Mycobacterium tuberculosis $\mathrm{ClpP} 1$ and $\mathrm{ClpP} 2$ function together in protein degradation and are required for viability in vitro and during infection. PLoS Pathog., 2012, vol. 8, no. 2: e1002511. doi: 10.1371/journal.ppat.1002511

50. Reed M.B., Gagneux S., DeRiemer K., Small P.M., Barry C.E. The W-Beijing lineage of Mycobacterium tuberculosis overproduces triglycerides and has the DosR dormancy regulon constitutively upregulated. J. Bacteriol., 2007, vol. 189, no. 7, pp. 25832589. doi: $10.1128 / J B .01670-06$

51. Rie A. van, Warren R., Richardson M., Victor T.C., Gie R.P., Enarson D.A., Beyers N., van Helden P.D. Exogenous reinfection as a cause of recurrent tuberculosis after curative treatment. N. Eng. J. Med., 1999, vol. 341, no. 16, pp. 1174-1179. doi: 10.1056/ NEJM199910143411602

52. Russell D.G., Barry C.E., Flynn J.L. Tuberculosis: what we don't know can, and does, hurt us. Science, 2010, vol. 328, no. 5980, pp. 852-856. doi: 10.1126/science. 1184784

53. Schmitt E.K., Riwanto M., Sambandamurthy V., Roggo S., Miault C., Zwingelstein C., Krastel P., Noble C., Beer D., Rao S.P., $\mathrm{Au} \mathrm{M}$. The natural product cyclomarin kills Mycobacterium tuberculosis by targeting the $\mathrm{ClpC1}$ subunit of the caseinolytic protease. Angewandte Chemie, 2011, vol. 123, no. 26, pp. 6011-6013. doi: 10.1002/ange.201101740

54. Shi W., Chen J., Zhang S., Zhang W., Zhang Y. Identification of novel mutations in LprG (rv1411c), rv0521, rv3630, rv0010c, ppsC, cyp128 associated with pyrazinoic acid/pyrazinamide resistance in Mycobacterium tuberculosis. Antimicrob. Agents. Chemother., 2018, vol. 62, no. 7: e00430-18. doi: 10.1128/AAC.00430-18

55. Shi W., Zhang X., Jiang X., Yuan H., Lee, J.S., Barry C.E., Wang H., Zhang W., Zhang, Y.Pyrazinamide inhibits trans-translation in Mycobacterium tuberculosis. Science, 2011, vol. 333, pp. 1630-1632. doi: 10.1126/science. 1208813

56. Sreevatsan S., Pan X., Zhang Y., Kreiswirth B.N., Musser J.M. Mutations associated with pyrazinamide resistance in $p n c A$ of Mycobacterium tuberculosis complex organisms. Antimicrob. Agents. Chemother., 1997, vol. 41, no. 3, pp. 636-640.

57. Stallings C.L., Stephanou N.C., Chu L., Hochschild A., Nickels B.E., Glickman M.S. CarD is an essential regulator of rRNA transcription required for Mycobacterium tuberculosis persistence. Cell, 2009, vol. 138, no. 1, pp. 146-159. doi: 10.1016/j.cell.2009.04.041

58. Syal K., Flentie K., Bhardwaj N., Maiti K., Jayaraman N., Stallings C.L., Chatterji D. Synthetic (p) ppGpp analogue: inhibitor of stringent response in mycobacteria. Antimicrob. Agents. Chemother., 2017, vol. 61, iss. 6: e00443-17. doi: 10.1128/AAC.00443-17

59. Van Deun A., Salim H., Kumar Das A.P., Bastian I., Portaels F. Results of a standardised regimen for multidrug-resistant tuberculosis in Bangladesh. Int. J. Tuberc. Lung Dis., 2004, vol. 8, no. 5, pp. 560-567.

60. Vasudevan D., Rao S.P., Noble C.G. Structural basis of mycobacterial inhibition by cyclomarin A. J. Biol. Chem., 2013, vol. 288, no. 43: 30883-91. doi: 10.1074/jbc.M113.493767

61. Via L.E., Savic R., Weiner D.M., Zimmerman M.D., Prideaux B., Irwin S.M., Lyon E., O’Brien P., Gopal P., Eum S., Lee M. Host-mediated bioactivation of pyrazinamide: implications for efficacy, resistance, and therapeutic alternatives. ACS Inf. Dis., 2015, vol. 1, no. 5, pp. 203-214. doi: 10.1021/id500028m

62. Vilchèze C., Weinrick B., Wong K.W., Chen B., Jacobs, Jr W.R. NAD ${ }^{+}$auxotrophy is bacteriocidal for the tubercle bacilli. Mol. Microbiol., 2010, vol. 76, no. 2, pp. 365-377. doi: 10.1111/j.1365-2958.2010.07099.x

63. Werngren J., Alm E., Mansjö M. Non-pncA Gene-mutated but pyrazinamide-resistant Mycobacterium tuberculosis: why is that? J. Clin. Microbiol., 2017, vol. 55, pp. 1920-1927. doi: 10.1128/JCM.02532-16

64. Wexselblatt E., Oppenheimer-Shaanan Y., Kaspy I., London N., Schueler-Furman O., Yavin E., Glaser G., Katzhendler J., Ben-Yehuda S. Relacin, a novel antibacterial agent targeting the stringent response. PLoS Pathog., 2012, vol. 8, no. 9: e1002925. doi: 10.1371/journal.ppat.1002925 
65. Wollenberg K.R., Desjardins C.A., Zalutskaya A., Slodovnikova V., Oler A.J., Quiñones Abeel T., Chapman S.B., Tartakovsky M., Gabrielian A., Hoffner S., Skrahin A., Birren B.W., Rosenthal A., Skrahina A., Earl A.M. Whole-genome sequencing of Mycobacterium tuberculosis provides insight into the evolution and genetic composition of drug-resistant tuberculosis in Belarus. J. Clin. Microbiol., 2017, vol. 55, pp. 457-469. doi: 10.1128/JCM.02116-16

66. Yee M., Gopal P., Dick T. Missense mutations in the unfoldase ClpC1 of the caseinolytic protease complex are associated with pyrazinamide resistance in Mycobacterium tuberculosis. Antimicrob. Agents Chemother., 2017, vol. 61: e02342-16. doi: 10.1128/ AAC.02342-16

67. Zhang S., Chen J., Shi W., Cui P., Zhang J., Cho S., Zhang W., Zhang Y. Mutation in clpCl encoding an ATP-dependent ATPase involved in protein degradation is associated with pyrazinamide resistance in Mycobacterium tuberculosis. Emerg. Microbes Infect., 2017, vol. 6: e8. doi: 10.1038/emi.2017.1

\section{Авторы:}

Энтони P.М., старший научный сотрудник, Национальный институт общественного здоровья и окружающей среды, г. Билтховен, Нидерланды;

Ден Хертог А.Л., преподаватель, Институт медикобиологических наук и химии, Университет прикладных наук, г. Утрехт, Нидерланды.

\section{Authors:}

Anthony R.M., Senior Scientist, National Institute for Public Health and the Environment (RIVM), Bilthoven, The Netherlands; den Hertog A.L., PhD Lecturer, Institute for Life Sciences and Chemistry, HU University of Applied Sciences, Utrecht, The Netherlands. 